\title{
Coupling Reactions and Coupling-Alkylations of Thiophenecarbaldehydes Promoted by Samarium Diiodide
}

\author{
Shyh-Ming Yang ${ }^{\dagger}$ and J im-Min Fang* \\ Department of Chemistry, National Taiwan University, Taipei 106, Taiwan, Republic of China \\ Received May 6, 1998
}

\begin{abstract}
The coupling reactions of 2-thiophenecarbaldehyde with aromatic or aliphatic aldehydes were promoted by samarium di iodide in the presence of hexamethylphosphoramide to give C-5 hydroxyalkylation products. The coupling reactions of 3-thiophenecarbaldehyde occurred at C-2, and the subsequent alkylations occurred at the sulfur atom, accompanied by a concurrent opening of the thiophene ring to afford $\gamma$-lactols. Double hydroxyalkylations of 2- and 3-thiophenecarbaldehydes were al so carried out under appropriate reaction conditions. Synthetic applications of these thiophenecarbonyl coupling products were demonstrated, for example, by elaboration to furans, butenolides, and thiophene-fused polycyclic compounds.
\end{abstract}

\section{Introduction}

Aromatic aldehydes usually undergo reductive carbonyl-carbonyl coupling reactions ${ }^{1}$ to give pinacols by using $\mathrm{Sml}_{2}$ or other suitable reducing agents. However, we have found that the coupling reactions of benzaldehydes or indole-3-carbaldehydes by using Sml $2 / \mathrm{HMPA}$ as the combined promoter proceed in a different mode to give aryl-carbonyl coupling products. ${ }^{2}$ This new type of coupling reactions is further extended to the system of 2- and 3-thiophenecarbaldehydes. ${ }^{3}$ Thiophenecarbaldehydes are generally reduced to the thienylmethanols by catalytic hydrogenation ${ }^{4}$ or with $\mathrm{LiAlH}_{4}{ }^{5}$ or $\mathrm{Fe} / \mathrm{HOAc}^{6}$ On treatment with $\mathrm{Mg} / \mathrm{Mgl}_{2}$, thiophenecarbaldehydes undergo self-coupling reactions to give pinacols. ${ }^{7}$ Electrochemical reductions of acetylthiophene or benzoylthiophene also give pinacols. ${ }^{8}$ Reductions of alkanoylthiophenes with dissolving metal s such as $\mathrm{Li} / \mathrm{NH}_{3}$ or $\mathrm{Na}$ / $\mathrm{NH}_{3}$ give the corresponding 2,5-dihydro derivatives. ${ }^{9}$ Reductions of thiophenes to tetrahydrothiophenes are achieved by using $\mathrm{Et}_{3} \mathrm{SiH} / \mathrm{CF}_{3} \mathrm{CO}_{2} \mathrm{H} .{ }^{10}$ We report herein

${ }^{\dagger}$ A recipient of Li-Ching Graduate Thesis Scholarship.

(1) For reviews of pinacolic coupling reactions, see: (a) Kahn, B. E.; Rieke, R. D. Chem. Rev. 1988, 88, 733. (b) Robertson, G. M. in Comprehensive Organic Synthesis; Trost, B. M., Fleming, I., Eds: Pergamon: Oxford, 1991; Vol. 3, pp 563-611. (c) Pons, J.-M.; Santelli, M. Tetrahedron 1988, 44, 4295. (d) Wirth, T. Angew. Chem., Int. Ed. Engl. 1996, 35, 61. (e) Molander, G. A.; Harris, C. R. Chem. Rev. 1996, 96,307 . For a pioneering work on the $\mathrm{Sml}_{2}$-induced pinacolic coupling reactions, see: (f) Namy, J . L.; Souppe, J .; Kagan, H. B. Tetrahedron Lett. 1983, 24, 765. More references with regard to the use of $\mathrm{Sml}_{2}$ for pinacolic couplings are cited; see: (g) Lu, L.; Fang, J .-M.; Lee, G.-H.; Wang, Y.J . Chin. Chem. Soc. 1997, 44, 279.

(2) (a) Shiue, J .-S.; Lin, C.-C.; Fang, J .-M. Tetrahedron Lett. 1993, 34, 335. (b) Shiue, J.-S.; Fang, J .-M. J . Chem. Soc., Chem. Commun. 1993, 1277. (c) Shiue, J .-S.; Lin, M.-H.; Fang, J .-M. J . Org. Chem. 1997, 62, 4643. (d) Lin, S.-C.; Yang, F.-D.; Shiue, J .-S.; Yang, S.-M.; Fang, J.-M. J . Org. Chem. 1998, 63, 2909.

(3) (a) Yang, S.-M.; Fang, J.-M. J . Chem. Soc., Perkin Trans. 11995 2669. For the related work on the coupling reactions of methyl thiophene-2-carboxylate, see: (b) Yang, S.-M.; Fang, J .-M. Tetrahedron Lett. 1997, 38, 1589.

(4) Wender, I.; Levine, R.; Orchin, M. J . Am. Chem. Soc. 1950, 72 4375.

(5) Cervinka, O.; Malon, P.; Procházková, H. Collect. Czech. Chem. Commun. 1974, 39, 1869 .

(6) (a) Emerson, W. S.; Ratrick, T. M. J . Org. Chem. 1949, 14, 790. (b) Clarke, H. T.; Dreger, E. E. Org. Synth. 1941, 304.

(7) (a) Gomberg, M.; Bachmann, W. E. J . Am. Chem. Soc. 1927, 49, 236. (b) Kegelman, M. R.; Brown, E. V. J . Am. Chem. Soc. 1953, 75 5961.

(8) Kryukova, E. V.; Tomilov, A. P. Elektrokhimiya 1969, 5, 869 (Chem. Abstr. 1969, 71, 76739j).
Table 1. Sml 2 -Promoted Coupling Reactions of 2-Thiophenecarbaldehyde (1) in THFa

\begin{tabular}{|c|c|c|c|}
\hline entry & substrates $(\mathrm{RCHO})$ & additive & $\begin{array}{l}\text { coupling } \\
\text { products } \\
\text { (\% yield) }\end{array}$ \\
\hline 1 & 1 & none & $4 \mathbf{a}(48)$ \\
\hline 2 & $\mathbf{1}$ & none & $4 a(65)$ \\
\hline 3 & $\mathbf{1}$ & HMPA & $3 a(45)$ \\
\hline 4 & $\mathbf{1}+3$-thiophenecarbaldehyde & HMPA & $\mathbf{3 b}(49)$ \\
\hline 5 & $\mathbf{1}+4-\mathrm{MeOC}_{6} \mathrm{H}_{4} \mathrm{CHO}$ & HMPA & $3 c(45)$ \\
\hline 6 & 1 + 1-methyl-2-pyrrolecarbal dehyde & HMPA & 3d (36) \\
\hline 7 & $\mathbf{1}+\mathrm{CH}_{3} \mathrm{CH}_{2} \mathrm{CHO}$ & HMPA & $\begin{array}{r}3 a(24)+ \\
3 e(49)\end{array}$ \\
\hline
\end{tabular}

a For entry 1 , the molar ratio of $\mathbf{1} / \mathrm{Sml}_{2}=1: 1.8$; for entry 2 , the molar ratio of $\mathbf{1} / \mathrm{Sml}_{2}=1: 1.2$; for entry 3 , the molar ratio of $\mathbf{1} / \mathrm{Sml} 2 /$ HMPA = 1:1.8:8; for entries 4-7, the molar ratio of $\mathbf{1} / \mathrm{RCHO} / \mathrm{Sml}_{2} /$ $\mathrm{HMPA}=1: 1.2: 3.6: 16$. The reactions were conducted by dropwise addition of $\mathbf{1}$ (or a mixture of $\mathbf{1}$ and $\mathrm{RCHO}$ ) to the $\mathrm{Sml}_{2}$ solution. The mixture was stirred at $0{ }^{\circ} \mathrm{C}$ to room temperature for $0.5-1.5$ h. ${ }^{b}$ The starting material $\mathbf{1}$ was recovered $(13-25 \%)$.

the thiophenecarbonyl coupling reactions of 2- and 3-thiophenecarbal dehydes ( $\mathbf{1}$ and $\mathbf{2}$ ) by mediation of $\mathrm{Sml}_{2} /$ HMPA. Along this line, we also found a method for elaboration of thiophenecarbaldehydes to furans, $\alpha, \beta$ unsaturated- $\gamma$-lactones, and various thiophene-fused polycyclic compounds including heterocyclic analogues of neolignans.

\section{Results and Discussion}

We studied first the coupling reactions of 2-thiophenecarbaldehyde (1) promoted by $\mathrm{Sml}_{2}$ (1.8 molar proportion) in THF solution (Table 1). In the presence of HMPA (8 $M$ proportion), a thiophenecarbonyl coupling product 3a was obtained in $45 \%$ yield. A significant amount (17\%) of the starting material $\mathbf{1}$ was also recovered. No pinacolic coupling product was observed under such reaction conditions. The reaction was presumably initiated by sequential electron transfers from $\mathrm{Sml}_{2}$ to 2 -thiophenecarbal dehyde to form the $\mathrm{C}-3$ organosamarium intermediate $\mathbf{A}$ or the C-5 organosamarium intermediate $\mathbf{B}$ (Scheme 1). The C-5 organosamarium B was presumably

(9) (a) Blenderman, W. G.; J oullié, M. M. Tetrahedron Lett. 1979 4985. (b) Blenderman, W. G.; J oullié, M. M. Synth. Commun. 1981 $11,881$.

(10) Kursanov, D. N.; Parnes, Z. N.; Bolestova, G. I.; Belen'kii, L. I . Tetrahedron 1975, 31, 311. 


\section{Scheme 1}
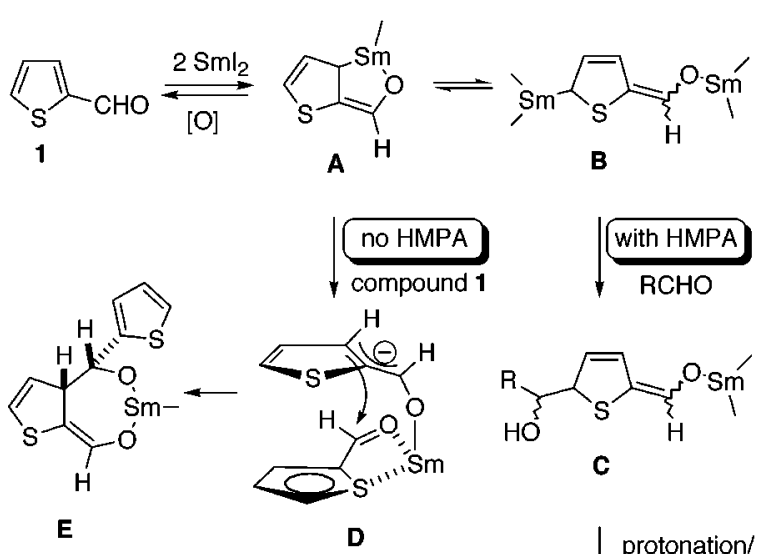

compound 1
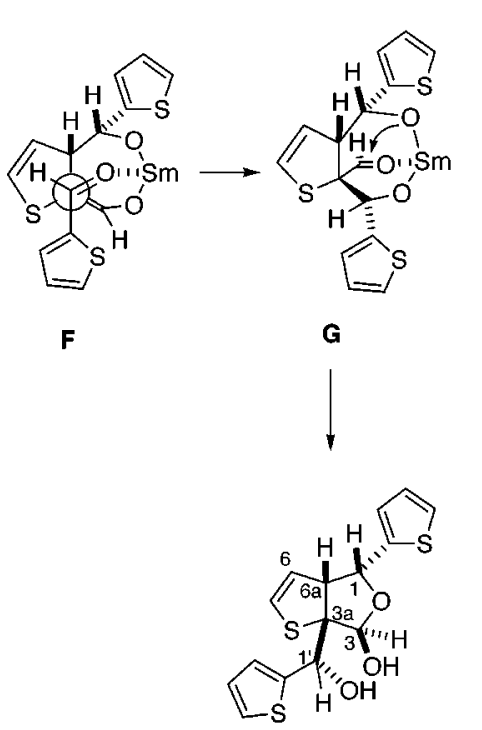

$( \pm)-4 a$

(major diastereomer)

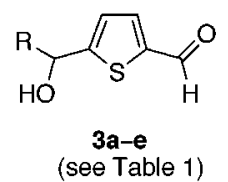

(see Table 1)

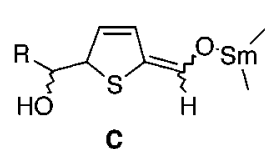

protonation' autoxidation
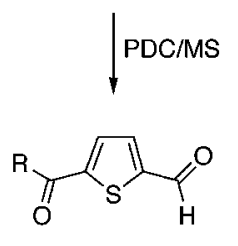

5 a $(89 \%)$

$\mathrm{R}=2$-thienyl

$5 \mathbf{b}(83 \%)$

$\mathrm{R}=3$-thienyl

5 c $(86 \%)$

$\mathrm{R}=4-\mathrm{MeOC}_{6} \mathrm{H}_{4}$

$5 \mathrm{~d}(84 \%)$

$R=1-$ methyl-2-pyrrolyl

5 e $(72 \%)$

$\mathrm{R}=$ ethyl

favored due to the stabilizing effect of the adjacent sulfur atom. ${ }^{11 a}$ Theoretically, half of 2-thiophenecarbaldehyde would be converted to the samarium species to function as a donor and another half of 2-thi ophenecarbaldehyde would act as an acceptor to furnish the coupling reaction. Thus, addition of $\mathbf{B}$ with a second molecule of 2-thiophenecarbaldehyde, giving $\mathbf{C}$, followed by protonation and oxi dative rearomatization upon workup, would give the thiophenecarbonyl coupling product 3a. Otherwise, the unreacted intermediate $\mathbf{B}$ (or $\mathbf{A}$ ) might revert to the aromatic starting material $\mathbf{1}$ upon autoxidation. ${ }^{2}$

The dipolar cosolvent HMPA is known to alter the regioselectivity in the reactions of allylmetals. ${ }^{11}$ Interestingly, the reaction of $\mathbf{1}$ with $\mathrm{Sml}_{2}$ (1.2 M proportion) in the absence of HMPA gave a mixture of the trimeric product 4a and its diastereomers, as indicated by the ${ }^{1} \mathrm{H}$ NMR analysis. The major diastereomer $\mathbf{4 a}$ (40\% yield)

(11) The cosolvent HMPA and other factors such as substituents, attacking electrophiles, and countercations can alter the regiochemistry in the reactions of allylmetals and related systems; see: (a) Evans, D. A.; Andrews, G. C. Acc. Chem. Res. 1974, 7, 147. (b) Biellmann, J . F. Ducep, J . B. Org. React. 1982, 27, 1. (c) Ogura, K. In Comprehensive Organic Synthesis; Trost, B. M., Fleming, I., Eds.; Pergamon Press: Oxford, 1991; Vol. 1, pp 505-539. (d) Roush, W. R. In Comprehensive Organic Synthesis, Trost, B. M., Fleming, I., Eds.; Pergamon Press: Oxford, 1991; Vol. 2, pp 1-98.

was isolated by trituration of the reaction mixture with EtOAc/hexane. A recrystallized sample was subjected to $\mathrm{X}$-ray diffraction to reveal the $\left(1 \mathrm{R} *, \mathrm{I}^{\prime} \mathrm{R} *, 3 \mathrm{R} *, 3 \mathrm{aS} *, 6 \mathrm{aR} *\right)$ configuration of this major diastereomer. To account for the formation of this product, the chelate organosamarium species A was considered to dominate over $\mathbf{B}$ in the absence of HMPA. The C-3 organosamarium intermediate $\mathbf{A}$ could add to a second molecule of 2-thiophenecarbal dehyde via a transition state $\mathbf{D}$ having two stacked thiacycles (Scheme 1). The resulting samarium enolate $\mathbf{E}$ was then trapped by a third molecule of 2-thiophenecarbaldehyde, presumably following the favored chelate form $\mathbf{F}$, to give an aldehyde $\mathbf{G}$. The subsequent intramolecular hemiacetalization would occur in a stereoselective manner to furnish $\left(1 R^{*}, I^{\prime} R^{*}, 3 R^{*}\right.$, $3 \mathrm{aS} *, 6 \mathrm{aR} *)-4 a$.

A cross-coupling reaction between 2-thiophenecarbaldehyde (1.0 equiv) and 3-thiophenecarbaldehyde (1.2 equiv) was effected by $\mathrm{Sml}_{2}$ (3.6 equiv) in the presence of HMPA (16 equiv) to afford a single product $\mathbf{3 b}(49 \%)$. This result indicated that 2-thiophenecarbal dehyde was more reactive toward $\mathrm{Sml}_{2}$ to form organosamarium species. Thus, 2-thiophenecarbal dehyde functioned as a donor, whereas 3-thiophenecarbaldehyde functioned as an acceptor in this cross-coupling reaction. Under similar reaction conditions, the cross-coupling reactions of 2-thiophenecarbal dehyde with other al dehydes were also carried out (Table 1). The self-coupling of $\mathbf{1}$ was diminished except for the reaction with propionaldehyde, a relatively unreactive substrate toward $\mathrm{Sml}{ }_{2}$ reduction. The coupling products $\mathbf{3 a}-\mathbf{e}$ were oxidized by PDC to give the corresponding thiophene-2,5-dicarbonyl compounds $\mathbf{5 a}-\mathbf{e}$ in high yields. These compounds are potentially useful for the preparation of macrocycles and tris-1,3dithiole photoelectric material. ${ }^{12}$

We then studied the coupling reactions of 3-thiophenecarbaldehyde (2) by using $\mathrm{Sml}_{2}$ in THF solution (Table 2). Unlike the coupling reactions of $\mathbf{1}$, the thiophenecarbonyl coupling reaction of $\mathbf{2}$ was complicated by a pinacolic coupling reaction. In the absence of HMPA (entries 1 and 2), the $\mathrm{Sml}_{2}$-promoted reaction afforded pinacols 6, dimer 7a, and trimeric products $\mathbf{8}$ in variable yields (Scheme 2). In the presence of HMPA (entry 3 ), the thiophenecarbonyl coupling product $7 \mathrm{a}$ became the major product $(40-46 \%)$. However, the trimeric products $8(50 \%)$ and $9(9 \%)$ predominated (entry 4) when 3-thiophenecarbaldehyde (1 equiv) was treated with $\mathrm{Sml}_{2}$ (1.8 equiv) and HMPA (8 equiv) in THF solution for 10 min at $0{ }^{\circ} \mathrm{C}$ followed by addition of another 0.6 equiv of 3-thiophenecarbaldehyde.

According to the ${ }^{1} \mathrm{H}$ NMR spectral analysis, pinacols 6 existed as a mixture of two diastereomers (1:2). Compound $\mathbf{8}$ also existed as a mixture of hemiacetals, which was subjected to oxidation with PDC to give a lactone 10. Compound 9 was isolated as a single isomer; it was presumably derived by a hydride transfer from the hemiacetal 8 to 3 -thiophenecarbaldehyde. This deduction was supported by isolation of 3-thienylmethanol in a nearly equal amount. The coupling constants J $3,3 \mathrm{a}$ of $\mathbf{9}$ and $\mathbf{1 0}$ were 7.6 and $7.8 \mathrm{~Hz}$, respectively. By comparison

(12) For representative examples, see: (a) Armiger, Y. L. S.-T.; Lash, T. D. J . Heterocycl. Chem. 1992, 29, 523. (b) Benahmed-Gasmi, A. S.; Frere, P.; Garrigues, B.; Gorgues, A.; J ubault, M.; Carlier, R.; Texier, F. Tetrahedron Lett. 1992, 33, 6457. (c) Takimiya, K.; Otsubo, T.; Ogura, F.; Ashitaka, H.; M orita, K.; Suehiro, T. Chem. Lett. 1994, 255. (d) Ohta, A.; Yamashita, Y. Heterocycles 1995, 40, 123. 


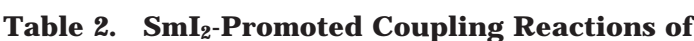
3-Thiophenecarbaldehyde (2) in THFa

\begin{tabular}{|c|c|c|c|}
\hline entry & substrates (RCHO) & additive & $\begin{array}{l}\text { coupling products } \\
(\% \text { yield })^{\mathrm{b}}\end{array}$ \\
\hline 1 & 2 & none & $\begin{array}{c}6(20)^{c}+7 \mathbf{a}(20)+ \\
\mathbf{8}^{c}(<5)\end{array}$ \\
\hline 2 & 2 & none & $\begin{array}{c}6(25)^{c}+7 a(15)+ \\
8^{c}(19)\end{array}$ \\
\hline $3^{d}$ & 2 & HMPA & $7 a(46)$ \\
\hline $4^{e}$ & & HMPA & $\begin{array}{c}6(5)^{c}+7 \mathbf{7 a}(10)+ \\
\mathbf{8}(50)^{c}+\mathbf{9}(9)\end{array}$ \\
\hline $\begin{array}{l}5 \\
6\end{array}$ & $\begin{array}{l}\mathbf{2}+4-\mathrm{MeOC}_{6} \mathrm{H}_{4} \mathrm{CHO} \\
\mathbf{2}+4-\mathrm{CH}_{3} \mathrm{C}_{6} \mathrm{H}_{4} \mathrm{CHO}\end{array}$ & $\begin{array}{l}\text { HMPA } \\
\text { HMPA }\end{array}$ & $\begin{array}{l}7 \mathbf{a}(18)+7 \mathbf{b}(43) \\
7 \mathbf{a}(17)+7 \mathbf{c}(37)\end{array}$ \\
\hline $7^{f}$ & $\begin{array}{l}\mathbf{2}+\text { 1-methyl-2-pyrrole- } \\
\text { carbaldehyde }\end{array}$ & HMPA & $7 \mathbf{a}(27)+7 \mathbf{d}(21)$ \\
\hline 8 & $2+\mathrm{CH}_{3} \mathrm{CH}_{2} \mathrm{CHO}$ & HMPA & $7 \mathbf{a}(22)+7 \mathbf{e}(43)$ \\
\hline
\end{tabular}

a For entry 1 , the molar ratio of $2 / \mathrm{Sml}_{2}=1: 1.8$; for entry 2 , the molar ratio of $2 / \mathrm{Sml}_{2}=1: 1.2$; for entry 3 , the molar ratio of $2 / \mathrm{Sml} 2 /$ HMPA = 1:1.8:8; for entries 5-8, the molar ratio of 2/RCHO/Sml $2 /$ HMPA = 1:1.2:3.6:16. The reactions were conducted by dropwise addition of $\mathbf{2}$ (or a mixture of $\mathbf{2}$ and $\mathrm{RCHO}$ ) to the $\mathrm{Sml}_{2}$ solution. The mixture was stirred at $0{ }^{\circ} \mathrm{C}$ to room temperature for $0.5-2 \mathrm{~h}$. ${ }^{b}$ The starting material 2 was recovered (14-38\%). ${ }^{c}$ The products consisted of diastereomers. d If $\mathbf{2}$ was added in one portion to the $\mathrm{Sml}_{2} / \mathrm{HMPA}$ solution, the reaction gave 6 (21\%) and $7 \mathrm{a}$ (40\%). If the $\mathrm{Sml} / \mathrm{HMPA}$ solution was added to the 3-thiophenecarbalde hyde solution, the reaction gave 6 (26\%) and $7 a(46 \%) .{ }^{e}$ Another 0.6 equiv of $\mathbf{2}$ was added after the mixture of $2 / 5 \mathrm{ml} / \mathrm{HMPA}$ ( 1 : $1.8: 8)$ was stirred at $0{ }^{\circ} \mathrm{C}$ for $10 \mathrm{~min}$. The reaction also gave a $13 \%$ of 3 -thienylmethanol. ${ }^{f}$ The side products were 3-thienylmethanol (14\%) and 2-hydroxy-1-(1-methyl pyrrol-2-yl)-2-(3-thienyl)ethanone (16\%).

with the coupling constant of $7.0 \mathrm{~Hz}$ for $\mathrm{H}_{1}-\mathrm{H}_{6 \mathrm{a}}$ of $\left(1 R^{*}, 1^{\prime} R^{*}, 3 R^{*}, 3 a S^{*}, 6 a R^{*}\right)-4 a$, the $\mathrm{H}-3$ and $\mathrm{H}-3 \mathrm{a}$ of 9 and 10 al so likely had the cis relationship. This result could also account for a chelate transition state J having two stacked thiacycles (Scheme 2). Addition of 3-thiophenecarbaldehyde to the enolate $\mathbf{K}$ should occur on the less hindered face, giving the aldehyde $\mathbf{L}$, which formed the hemiacetal 8 intramolecularly. The relative configuration of $C-1^{\prime}$ remained unknown, though it was likely $\mathrm{R}^{*}$ according to the mechanistic consideration.

By the promotion of Sml $2 / \mathrm{HMPA}$, 3-thiophenecarbaldehyde reacted with aromatic and aliphatic aldehydes to give the thiophenecarbonyl coupling products $\mathbf{7 b}-\mathbf{e}$ (entries 5-8, Table 2). Nonethel ess, the self-coupling of 2 (giving 7a) also competed with these cross-couplings. The reaction with 1-methyl-2-pyrrol ecarbaldehyde al so yielded 3-thienylmethanol and 2-hydroxy-1-(1-methylpyrrol-2-yl)-2-(3-thienyl)ethanone in nearly equal amounts (ca. $15 \%$ each). This result indicated that a side reaction of crossed pinacolic coupling between $\mathbf{2}$ and 1-methylpyrrole-2-carbal dehyde occurred and the resulting pinacol could transfer a hydride to the remaining aldehyde $\mathbf{2}$.

The key intermediate $\mathbf{M}$ (Scheme 3) in the coupling reactions of 3-thiophenecarbaldehyde was also trapped by alkylating agents. The alkylations occurred exclusively at the sulfur atom to effect a concurrent opening of the thiophene ring, giving the hemiacetals $\mathbf{1 1 a}-\mathbf{d}$ (Table 3 ). The double bonds of $\mathbf{1 1 a}-\mathbf{d}$ retained the $(Z)$ configuration as indicated by the coupling constants (ca. $10.5 \mathrm{~Hz}$ ) of the two adjacent vinyl protons. As trapping of the intermediate by alkylating agents drove the coupling reaction through the last irreversible step, the yields of $\mathbf{1 1 a}-\mathbf{d}(55-74 \%)$ were higher than those of dimers $7 \mathbf{a}-\mathbf{d}$ (21-46\%). The hemiacetals $11 \mathbf{a}-\mathbf{d}$ were oxidized by PDC to give $70-82 \%$ yields of the corresponding lactones $\mathbf{1 2} \mathbf{a}-\mathbf{d}$ with cis double bonds. It was noted that the hemiacetals were unstable in $\mathrm{CDCl}_{3}$ solution containing
Scheme 2

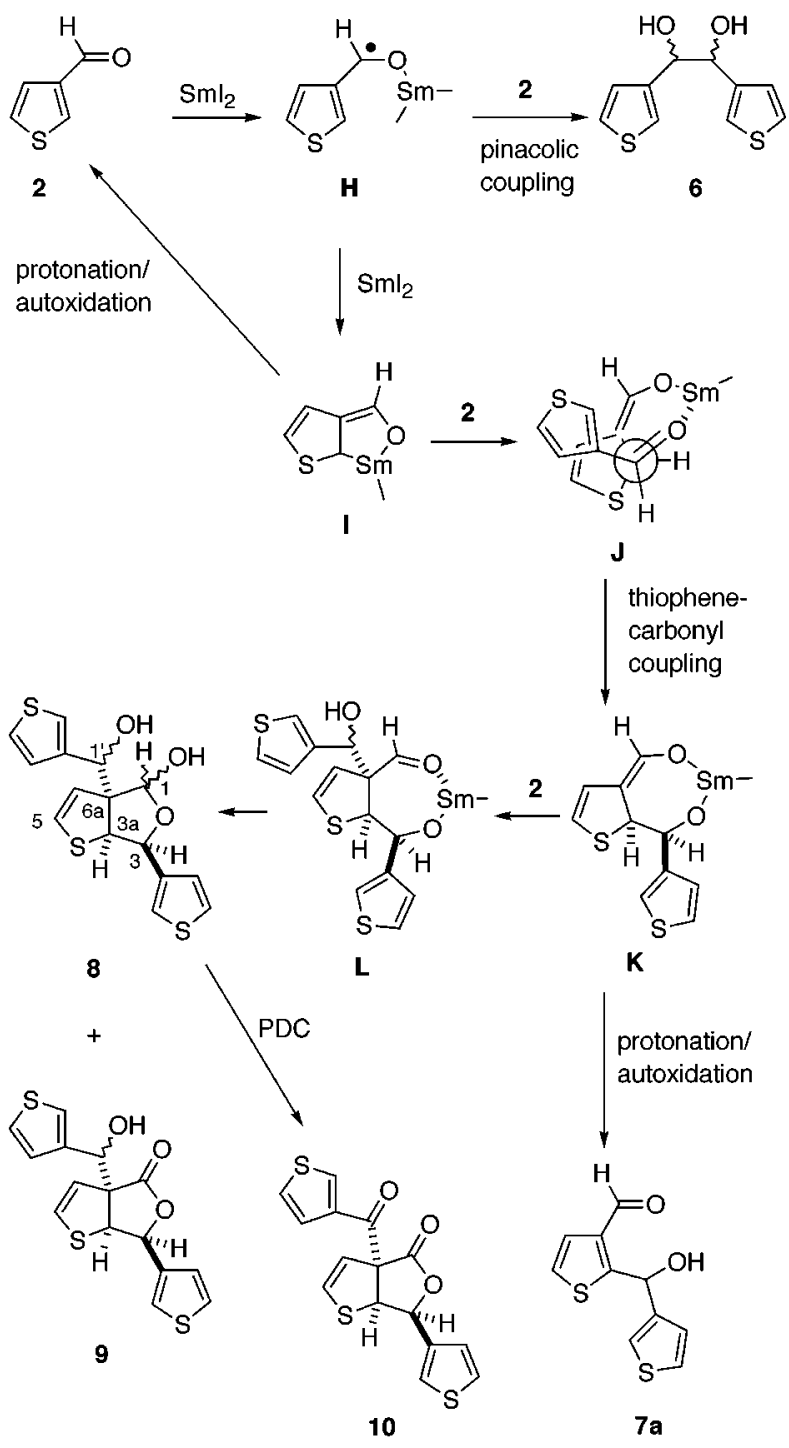

a small amount of DCl. Indeed, an acid-catalyzed dehydration of $\mathbf{1 1 b}$ was carried out to give a quantitative yield of the furan 13a with a cis double bond. (Z)-13a isomerized in part to ( $E)$-13a when it was subjected to chromatography on a silica gel column. The hemiacetal 11c was similarly converted to the furan $\mathbf{1 3 \mathbf { b }}$ by acid catalysis. This sequential thiophenecarbonyl coupling-alkylation method thus provides a convenient route to furans and butenolides, which often exhibit important biological activities. ${ }^{13}$

This method is also applicable to the synthesis of thiophene-fused polycyclic compounds. The coupling products $\mathbf{7 a}, \mathbf{b}$ were similarly oxidized by PDC to give thiophene-2,3-dicarbonyl compounds $\mathbf{1 4 a , b}$, which reacted further with hydrazine to give thieno[2,3-d]pyridazines 15a,b (Scheme 4). The thienopyriazones related to $\mathbf{1 5 a}, \mathbf{b}$ have been used as antiasthmatic drugs. ${ }^{14}$ The coupling products $\mathbf{7 a -}$ c were treated with Lawesson's

(13) F or representative reviews and examples, see: (a) Tsuboi, S. Wada, H.; Muranaka, K.; Takeda, A. Bull. Chem. Soc. J pn. 1987, 60, 2917. (b) Tsubuki, M. J . Synth. Org. Chem. 1993, 51, 399. (c) Marles, R. J .; Pazos-Sanou, L.; Compadre, C. M.; Pezzuto, J. M.; Bloszyk, E Amason, J. T. Recent Adv. Phytochem. 1995, 29, 333. (d) Collins, I. Contemp. Org. Synth. 1997, 4, 281.

(14) Yamaguchi, M.; Maruyama, N.; Koga, T.; Kamei, K. Chem Pharm. Bull. 1995, 43, 236. 
Scheme 3<smiles>O=CC=CC=O</smiles>

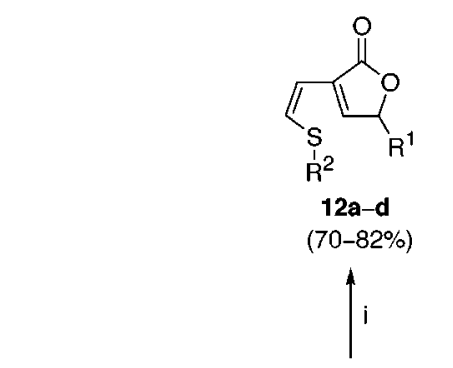

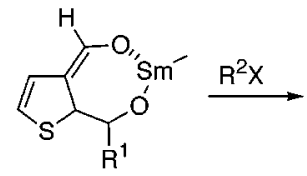

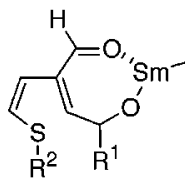<smiles>Cc1cc(C)cc(O)c1</smiles>

$\mathbf{N}$

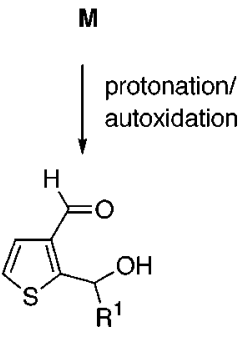

$7 b-d$ (see Table 2)

a Reagents and conditions: (i) PDC, $\mathrm{CH}_{2} \mathrm{Cl}_{2}$, sieves, 3-7 h, 12a $77 \%, \mathbf{1 2 b} 79 \%, \mathbf{1 2 c} 82 \%, \mathbf{1 2 d} 70 \%$; (ii) cat. $\mathrm{HCl}$ in $\mathrm{CHCl}_{3}, \mathbf{1 3 a}$ $100 \%$, 13b $100 \%$.

Table 3. Sequential Coupling-Alkylations of 3-Thiophenecarbaldehyde (2)

\begin{tabular}{|c|c|c|c|}
\hline entry & $\begin{array}{l}\text { substrates } \\
\left(\mathrm{R}^{1} \mathrm{CHO}\right)\end{array}$ & $\mathrm{R}^{2} \mathrm{X}$ (equiv) & $\begin{array}{l}\text { products } \\
\text { (\% yield) }\end{array}$ \\
\hline 1 & 2 & allyl bromide (1) & $\begin{array}{c}\mathbf{6}^{\mathrm{b}}(18)+7 \mathbf{a}(38)+ \\
\mathbf{1 1}^{\mathrm{b}}(20)\end{array}$ \\
\hline $\begin{array}{l}2 \\
3 \\
4 \\
5\end{array}$ & $\begin{array}{l}2 \\
2 \\
2 \\
2\end{array}$ & $\begin{array}{l}\text { allyl bromide (2) } \\
\text { benzyl bromide (1) } \\
\text { benzyl bromide (2) } \\
\text { dimethyl sulfate (2.5) }\end{array}$ & $\begin{array}{l}\mathbf{6}^{\mathrm{b}}(5)+\mathbf{1 1} \mathbf{a}^{\mathrm{b}}(55) \\
\mathbf{6}^{\mathrm{b}}(15)+\mathbf{1 1}^{\mathrm{b}}(46) \\
\mathbf{6}^{\mathrm{b}}(13)+\mathbf{1 1}^{\mathrm{b}}(65) \\
\mathbf{6}^{\mathrm{b}}(\mathbf{7})+\mathbf{7 a}(29)+ \\
\quad \mathbf{1 1} \mathbf{c}^{\mathrm{b}}(29)\end{array}$ \\
\hline $\begin{array}{l}6 \\
7\end{array}$ & $\begin{array}{l}2 \\
\mathbf{2}+4-\mathrm{MeOC}_{6-}^{-} \\
\\
\mathrm{H}_{4} \mathrm{CHO}\end{array}$ & $\begin{array}{l}\text { methyl iodide (2.5) } \\
\text { benzyl bromide (2) }\end{array}$ & $\begin{array}{l}\mathbf{6}^{\mathrm{b}}(8)+11 \mathbf{c}^{\mathrm{b}}(74) \\
\mathbf{1 1}^{\mathrm{b}}(22)+ \\
11 \mathbf{d}^{\mathrm{b}}(63)\end{array}$ \\
\hline
\end{tabular}

a Refer to Scheme 3 for these sequential reactions. ${ }^{b}$ The products existed as diastereomeric mixtures.

reagent to give thieno[2,3-c]thiophenes $\mathbf{1 6 a - c}$ in $81-88 \%$ yields. Compound $7 \mathbf{a}$ was heated with benzylamine in the presence of $\mathrm{p}$ - $\mathrm{TsOH}$ to give an unstable product of thieno[2,3-c]pyrrole 17, which displayed a characteristic signal at $\delta_{\mathrm{H}} 5.40(2 \mathrm{H}, \mathrm{s})$ for the $\mathrm{N}$-benzyl group in addition to other signals for aromatic protons. The acidcatalyzed dehydration of $7 \mathbf{7 a}$ also led to an unstable thieno[2,3-c]furan $\mathbf{1 8}$ of which $\mathrm{H}-1$ occurred at $\delta 7.73$ (s). Compounds $\mathbf{1 6 a}-\mathbf{c}, \mathbf{1 7}$, and $\mathbf{1 8}$ can serve as the equivalents of thiophene-2,3-quinodimethane employed as the diene substrates in Diels-Alder reactions. ${ }^{15}$ Thus, condensation of $\mathbf{7 a}-\mathbf{c}$ with dimethyl acetylenedicarboxylate was carried out by the catalysis of PPTS to give benzothiophenes $19 \mathbf{a}-\mathbf{c}$ in $89-92 \%$ yields. Cycloadditions of

(15) (a) Pindur, U .; Erfanian-Abdoust, H. Chem. Rev. 1989, 89, 1681. (b) Sha, C.-K.; Tsou, C.-P. Tetrahedron 1993, 49, 6831. (c) Sha, C.-K.; Tsou, C.-P. J . Chem. Soc., Perkin Trans. 1 1994, 3065.

\section{Scheme 4}

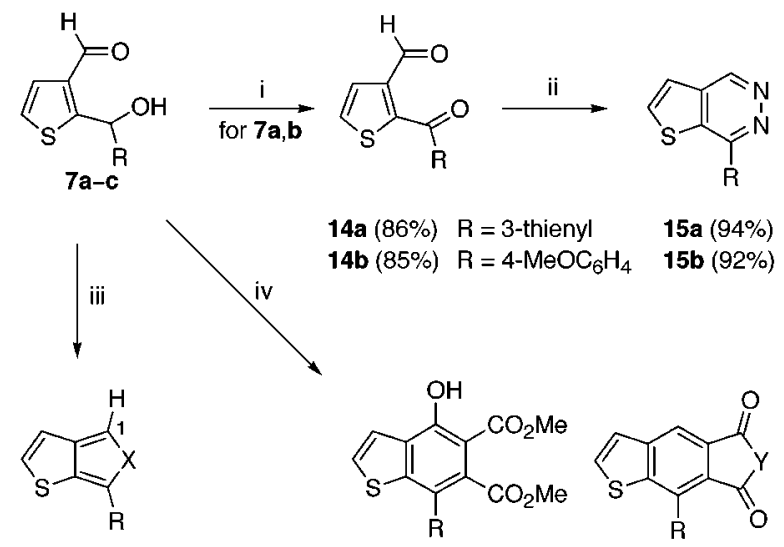

16a $(85 \%) X=S \quad R=3$-thienyl $\quad 19 a(91 \%) \quad 20 a(89 \%) Y=N P h$ $16 \mathrm{~b}(88 \%) \mathrm{X}=\mathrm{S} \quad \mathrm{R}=4-\mathrm{MeOC}_{6} \mathrm{H}_{4} \quad 19 \mathrm{~b}(92 \%) \quad 20 \mathrm{~b}(92 \%) Y=N P h$ 16c $(81 \%) X=S \quad R=4-\mathrm{CH}_{3} \mathrm{C}_{6} \mathrm{H}_{4} \quad 19 \mathrm{c}(89 \%) \quad 20 \mathrm{c}(94 \%) \mathrm{Y}=\mathrm{NPh}$ $17 \mathrm{X}=\mathrm{NCH}_{2} \mathrm{Ph} \quad \mathrm{R}=3$-thienyl $21(67 \%) \mathrm{Y}=\mathrm{O}$, $18 X=0 \quad R=3$-thienyl $\quad R=4-C_{3} \mathrm{C}_{6} \mathrm{H}_{4}$

a Reagents and conditions: (i) PDC, $\mathrm{CH}_{2} \mathrm{Cl}_{2}, \mathrm{rt}, 2.5 \mathrm{~h}$; (ii) $\mathrm{N}_{2} \mathrm{H}_{4}$, $\mathrm{EtOH}, \mathrm{rt}$ (10 min) then reflux (20 min); (iii) F or 16a-c, Lawesson's reagent, 1,4-dioxane, reflux, $3 \mathrm{~h}$; for $\mathbf{1 7}, \mathrm{PhCH}_{2} \mathrm{NH}_{2}$, cat. PTSA, $\mathrm{PhH}$; for 18, cat. PPTS, $\mathrm{PhH}$; (iv) For $\mathbf{1 9 a}-\mathbf{c}$, dimethyl acetylenedicarboxylate, cat. PPTS, $\mathrm{PhH}, \mathbf{1 - 2} \mathrm{h}$; for $\mathbf{2 0 a}-\mathbf{c}, \mathrm{N}$-phenylmaleimide, cat. PPTS, PhH, 2 h; for 21, maleic anhydride, cat. PPTS, $\mathrm{PhH}, 2 \mathrm{~h}$.

7a-c with $\mathrm{N}$-phenylmaleimide or maleic anhydride were also realized by similar procedures. Compounds $\mathbf{1 9 a}, \mathbf{b}$ are heterocyclic analogues of 1-arylnaphthal ene lignans with antihyperlipidemic activity. ${ }^{16}$

A previous method ${ }^{17}$ for alkylation of thiophenecarbaldehydes requires sequential treatments with amine (such as $\mathrm{N}$-methylpiperazine) and BuLi (several molar proportions) at low temperatures to generate $\alpha$-aminoalkoxide intermediates. This procedure is tedious and the reaction shows variable regioselectivities depending on the reaction substrates and conditions. On the other hand, our present method using $\mathrm{Sml} / 2 / \mathrm{HMPA}$ as the promoter is relatively simple and gives the thiophenecarbonyl coupling products with predictable regiochemistry. The thiophenecarbonyl coupling products are versatile building blocks for the synthesis of thiophene-fused polycyclic compounds such as 15-21. Furthermore, we have demonstrated a novel way for the ring-opening of 3-thiophenecarbaldehyde by sequential coupling-alkylation to culminate in the formation of furans and $\alpha, \beta$-unsaturated $\gamma$-lactones such as $\mathbf{1 2}$ and $\mathbf{1 3 .}$

\section{Experimental Section}

Melting points are uncorrected. ${ }^{1} \mathrm{H}$ NMR spectra were recorded at 200,300 , or $400 \mathrm{MHz} ;{ }^{13} \mathrm{C}$ NMR spectra were recorded at 50, 75 , or $100 \mathrm{MHz}$. Tetramethylsilane and $\mathrm{CDCl}_{3}$ were used as internal standards in the ${ }^{1} \mathrm{H}$ and ${ }^{13} \mathrm{C}$ NMR spectra, respectively. Mass spectra were recorded at an ionizing voltage of 70 or $20 \mathrm{eV}$. High-resolution mass spectra were taken using an internal PFK reference followed by a computer

(16) (a) Kuroda, T.; Takahashi, M.; Ogiku, T.; Ohmizu, H.; Nishitani, T.; Kondo, K.; I wasaki, T. J . Org. Chem. 1994, 59, 7353. (b) Kuroda, T.; Takahashi, M.; Ogiku, T.; Ohmizu, H.; Kondo, K.; I wasaki, T. J. Chem. Soc., Chem. Commun. 1991, 1635. (c) Hutchinson, C. R. Tetrahedron 1981, 37, 1047. (d) Cardwell, K.; Hewitt, B.: Ladlow, M.; Magnus, P. J . Am. Chem. Soc. 1988, 110, 2242. (e) Gribble, G. W.; Saulnier, M. G. Heterocycles 1985, 23, 1277.

(17) (a) Comins, D. L.; Killpack, M. O. J . Org. Chem. 1987, 52, 104. (b) Comins, D. L. Synlett 1992, 615. 
search for the mass that best fit an elemental formula. Merck silica gel 60F sheets were used for analytical thin-layer chromatography. Column chromatography was performed on $\mathrm{SiO}_{2}$ (70-230 mesh); gradients of EtOAc and n-hexane were used as eluents. High-pressure liquid chromatography was carried out on a liquid chromatograph equipped with a refractive index detector. The samples were analyzed and/or separated on a Hibar Lichrosorb Si $60(7 \mu \mathrm{m})$ column $(25 \mathrm{~cm}$ $\times 1 \mathrm{~cm}$ ) with the indicated el uent with a $5 \mathrm{~mL} / \mathrm{min}$ flow rate. THF was distilled from sodium benzophenone ketyl under $\mathrm{N}_{2}$.

General Procedure for the Reactions of Thiophenecarbaldehydes with $\mathbf{S m l}_{2}$. Samarium metal (0.66 g, 4.4 $\mathrm{mmol}$ ) and 1,2-diiodoethane (1.02 g, $3.6 \mathrm{mmol})$ in anhydrous THF $(40 \mathrm{~mL})$ were stirred at room temperature under an argon atmosphere for $1 \mathrm{~h}$ to give a deep-blue solution. HMPA (2.8 $\mathrm{mL}, 16 \mathrm{mmol}$ ) was added in most cases. Precaution should be taken as HMPA is a toxic cancer suspect agent. The mixture was cooled to $0{ }^{\circ} \mathrm{C}$ in an ice bath, and a THF solution $(2 \mathrm{~mL})$ of thiophenecarbaldehyde $(2.0 \mathrm{mmol})$ (for self-coupling reactions) or a mixture of thiophenecarbaldehyde $(1 \mathrm{mmol})$ and an appropriate aldehyde (1.2 mmol) (for cross-coupling reactions) was added dropwise over a period of $2 \mathrm{~min}$. The lightyellow mixture was stirred at $0{ }^{\circ} \mathrm{C}$ for $10 \mathrm{~min}$ and warmed to room temperature over a period of $0.5-2 \mathrm{~h}$. Saturated $\mathrm{NH}_{4} \mathrm{Cl}_{(\mathrm{aq})}$ $(0.1 \mathrm{~mL})$ was added. The mixture was filtered through a pad of silica gel and rinsed with EtOAc/hexane (1:1). The organic phase was concentrated under reduced pressure and chromatographed on a silica gel column with elution of EtOAd hexane to give products.

5-[1-Hydroxy-(2-thienyl)methyl]thiophene-2-carbaldehyde (3a) and 5-(Thiophene-2-carbonyl)thiophene-2-carbaldehyde (5a). According to the general procedure, treatment of 2-thiophenecarbaldehyde ( $224 \mathrm{mg}, 2 \mathrm{mmol}$ ) with $\mathrm{Sml}_{2}$ ( $3.6 \mathrm{mmol})$ in the presence of HMPA $(16 \mathrm{mmol})$ gave the selfcoupling product $3 \mathbf{3}$ (100 mg, 45\%). By a procedure similar to that for 10, treatment of $\mathbf{3 a}$ ( $75 \mathrm{mg}, 0.33 \mathrm{mmol}$ ) with PDC (376 $\mathrm{mg}, 1.0 \mathrm{mmol})$ and molecular sieves $(4 \AA, 2 \mathrm{~g})$ in $\mathrm{CH}_{2} \mathrm{Cl}_{2}(10$ $\mathrm{mL}$ ) at $25{ }^{\circ} \mathrm{C}$ for $2 \mathrm{~h}$ gave 5 a (66 mg, 89\%). 3a: oil; TLC (EtOAc/hexane (3:7)) $\mathrm{R}_{\mathrm{f}}=0.2 ;{ }^{1} \mathrm{H} \mathrm{NMR}\left(\mathrm{CDCl}_{3}, 200 \mathrm{MHz}\right) \delta$ $9.74(1 \mathrm{H}, \mathrm{s}, \mathrm{CHO}), 7.58(1 \mathrm{H}, \mathrm{d}, \mathrm{J}=3.8 \mathrm{~Hz}), 7.27-7.20(1 \mathrm{H}$, $\mathrm{m}), 7.03-6.90(3 \mathrm{H}, \mathrm{m}), 6.22(1 \mathrm{H}, \mathrm{d}, \mathrm{J}=3.6 \mathrm{~Hz}), 3.95(1 \mathrm{H}, \mathrm{br}$ s, OH). 5a: solid; mp 102-103 ${ }^{\circ} \mathrm{C}$; TLC (EtOAc/hexane, 3:7) $\mathrm{R}_{\mathrm{f}}=0.26$; IR ( $\left.\mathrm{KBr}\right) 2802(\mathrm{CHO}), 1670(\mathrm{C}=\mathrm{O}), 1599(\mathrm{C}=\mathrm{O})$ $\mathrm{cm}^{-1} ;{ }^{1} \mathrm{H} N M R\left(\mathrm{CDCl}_{3}, 200 \mathrm{MHz}\right) \delta 9.98(1 \mathrm{H}, \mathrm{s}, \mathrm{CHO}), 7.90(1$ $\mathrm{H}, \mathrm{dd}, \mathrm{J}=3.8,1.0 \mathrm{~Hz}), 7.88(1 \mathrm{H}, \mathrm{d}, \mathrm{J}=3.9 \mathrm{~Hz}), 7.79(1 \mathrm{H}, \mathrm{d}$, $\mathrm{J}=3.9 \mathrm{~Hz}), 7.75(1 \mathrm{H}, \mathrm{dd}, \mathrm{J}=4.8,1.0 \mathrm{~Hz}), 7.19(1 \mathrm{H}, \mathrm{dd}, \mathrm{J}=$ 4.8, $\left.3.8 \mathrm{~Hz}) ;{ }^{13} \mathrm{C} \mathrm{NMR} \mathrm{(CDCl} 3,75 \mathrm{MHz}\right) \delta 183.3$ (d), 178.5 (s), 148.9 (s), 147.7 (s), 142.1 (s), 135.0 (d), 134.9 (d), 134.1 (d), 132.5 (d), 128.3 (d); MS m/z (rel intensity) $222\left(10, \mathrm{M}^{+}\right), 57$ (100); HRMS calcd for $\mathrm{C}_{10} \mathrm{H}_{6} \mathrm{O}_{2} \mathrm{~S}_{2} 221.9809$, found 221.9813.

1,3,6a-Trihydro-3-hydroxy-3a-[1-hydroxy-(2-thienyl)methyl]-1-(2-thienyl)thieno[2,3-c]furan (4a). According to the general procedure, treatment of 2-thiophenecarbaldehyde (336 mg, $3.0 \mathrm{mmol}$ ) with $\mathrm{Sml}_{2}(3.6 \mathrm{mmol}$ ) gave the trimeric product $4 a$ and its diastereomers $(220 \mathrm{mg}, 65 \%)$. The mixture was triturated with EtOAc/hexane (1:4) and filtered to give the major (1R*,1'R*,3R*,3aS*,6aR*)-4a isomer (136 mg, 40\%). The configuration was established by an X-ray diffraction analysis of a sample recrystallized from $\mathrm{CHCl}_{3} / \mathrm{cyclohexane}$. 4a: solid; $\mathrm{mp} 157.5-158.5^{\circ} \mathrm{C}$; TLC (EtOAc/hexane, 3:7) $\mathrm{R}_{\mathrm{f}}=$ 0.23; IR (KBr) 3481, $3381 \mathrm{~cm}^{-1}$; ${ }^{1} \mathrm{H} N M R\left(\mathrm{CD}_{3} \mathrm{COCD}_{3}, 200\right.$ $\mathrm{MHz}) \delta 7.33(2 \mathrm{H}, \mathrm{dd}, \mathrm{J}=4.7,1.2 \mathrm{~Hz}), 7.17(1 \mathrm{H}, \mathrm{dd}, \mathrm{J}=2.5$, $0.8 \mathrm{~Hz}), 7.01-6.88(3 \mathrm{H}, \mathrm{m}), 6.29(1 \mathrm{H}, \mathrm{d}, \mathrm{J}=3.3 \mathrm{~Hz}), 5.92(1$ $\mathrm{H}, \mathrm{dd}, \mathrm{J}=6.0,1.5 \mathrm{~Hz}), 5.80(1 \mathrm{H}, \mathrm{d}, \mathrm{J}=7.0 \mathrm{~Hz}), 5.73(1 \mathrm{H}, \mathrm{d}$, $\mathrm{J}=3.3 \mathrm{~Hz}), 5.57(1 \mathrm{H}, \mathrm{d}, \mathrm{J}=5.3 \mathrm{~Hz}), 4.83(1 \mathrm{H}, \mathrm{d}, \mathrm{J}=5.3$ $\mathrm{Hz}), 4.59(1 \mathrm{H}, \mathrm{dd}, \mathrm{J}=6.0,3.1 \mathrm{~Hz}), 3.74(1 \mathrm{H}, \mathrm{ddd}, \mathrm{J}=7.0$, 3.1, $1.5 \mathrm{~Hz}) ;{ }^{13} \mathrm{C}$ NMR $\left(\mathrm{CD}_{3} \mathrm{COCD}_{3}, 75 \mathrm{MHz}\right) \delta 146.1$ (s), 142.5 (s), 127.4 (d, C-5), 126.9 (d), 126.8 (d), 126.7 (d), 126.0 (d), 125.5 (d), 125.2 (d), 121.4 (d, C-6), 104.6 (d, C-3), 78.9 (s, C-3a), 78.6 (d, C-1), 72.7 (d, C-1'), 60.9 (d, C-6a); MS m/z (rel intensity) $338\left(31, \mathrm{M}^{+}\right), 113(100)$. Anal. Calcd for $\mathrm{C}_{15} \mathrm{H}_{14} \mathrm{O}_{3} \mathrm{~S}_{3}$ : C, 53.25; $\mathrm{H}, 4.17$. Found: $\mathrm{C}, 52.78 ; \mathrm{H}, 4.17$.

2-[1-Hydroxy-(3-thienyl)methyl]thiophene-3-carbaldehyde (7a). According to the general procedure, treatment of 3-thiophenecarbaldehyde (224 mg, 2 mmol) with $\mathrm{Sml}_{2}$ (3.6 mmol) in the presence of HMPA gave pinacol 6 (47 mg, 21\%) and the self-coupling product 7a (102 mg, 46\%) (40\%). 7a: oil; TLC (EtOAc/hexane, 1:4) $R_{f}=0.18$; IR (neat) $3378(\mathrm{OH}), 1658$ $(\mathrm{C}=\mathrm{O}) \mathrm{cm}^{-1} ;{ }^{1} \mathrm{H} \mathrm{NMR}\left(\mathrm{CDCl}_{3}, 200 \mathrm{MHz}\right) \delta 9.92(1 \mathrm{H}, \mathrm{s}, \mathrm{CHO})$, $7.43(1 \mathrm{H}, \mathrm{d}, \mathrm{J}=5.1 \mathrm{~Hz}, \mathrm{H}-5), 7.27(2 \mathrm{H}, \mathrm{m}), 7.20(1 \mathrm{H}, \mathrm{d}, \mathrm{J}=$ $5.1 \mathrm{~Hz}, \mathrm{H}-4), 7.08\left(1 \mathrm{H}, \mathrm{dd}, \mathrm{J}=4.4,1.9 \mathrm{~Hz}, \mathrm{H}-4^{\prime}\right), 6.42(1 \mathrm{H}$, $\mathrm{d}, \mathrm{J}=4.9 \mathrm{~Hz}), 4.43(1 \mathrm{H}, \mathrm{d}, \mathrm{J}=4.9 \mathrm{~Hz}, \mathrm{OH}) ;{ }^{13} \mathrm{C} \mathrm{NMR}\left(\mathrm{CDCl}_{3}\right.$ $50 \mathrm{MHz}) \delta 186.1$ (d), 158.3 (s), 142.8 (s), 136.1 (s), 129.8 (d), 126.1 (d), 126.0 (d), 124.3 (d), 122.4 (d), 66.9 (d); MS m/z (rel intensity) $224\left(100, \mathrm{M}^{+}\right.$); HRMS calcd for $\mathrm{C}_{10} \mathrm{H}_{8} \mathrm{O}_{2} \mathrm{~S}_{2} 223.9966$, found 223.9961. Anal. Calcd for $\mathrm{C}_{10} \mathrm{H}_{8} \mathrm{O}_{2} \mathrm{~S}_{2}$ : C, 53.57; $\mathrm{H}, 3.60$. Found: C, 53.56, H, 3.49 .

3,3a-Dihydro-6a-(1-hydroxy-(3-thienyl)methyl)-3-(3thienyl)thieno[2,3-c]furan-1-one (9) and 3,3a-Dihydro-3(3-thienyl)-6a-(thiophene-3-carbonyl)thieno[2,3-c]furan1-one (10). According to the general procedure, 3-thiophenecarbal dehyde (224 mg, $2 \mathrm{mmol}$ ) was added to the $\mathrm{Sml}_{2}$ (3.6 mmol)/ HMPA (16 mmol) solution. The mixture was stirred for $10 \mathrm{~min}$ at $0{ }^{\circ} \mathrm{C}$, and a second portion of 3-thiophenecarbaldehyde (135 $\mathrm{mg}, 1.2 \mathrm{mmol}$ ) was added. The mixture was stirred at room temperature for $10 \mathrm{~h}$ to give 8 (166 mg, 50\%), 9 (28 mg, 9\%), and 3-thienylmethanol (45 mg, 13\%). Compound 9 existed as a single isomer: oil; TLC (EtOAc/hexane, 3:7) $\mathrm{R}_{\mathrm{f}}=0.36$; IR (neat) $3468,1756 \mathrm{~cm}^{-1}$; ${ }^{1} \mathrm{H} \mathrm{NMR}\left(\mathrm{CDCl}_{3}, 200 \mathrm{MHz}\right) \delta 7.37-$ $7.31(2 \mathrm{H}, \mathrm{m}), 7.24-7.20(2 \mathrm{H}, \mathrm{m}), 7.04-7.00(2 \mathrm{H}, \mathrm{m}), 6.28$ (1 $\mathrm{H}, \mathrm{d}, \mathrm{J}=5.6 \mathrm{~Hz}, \mathrm{H}-5), 5.66(1 \mathrm{H}, \mathrm{d}, \mathrm{J}=5.6 \mathrm{~Hz}, \mathrm{H}-6), 5.25(1$ $\mathrm{H}, \mathrm{d}, \mathrm{J}=5.0 \mathrm{~Hz}, \mathrm{H}-1), 5.22(1 \mathrm{H}, \mathrm{d}, \mathrm{J}=7.4 \mathrm{~Hz}, \mathrm{H}-3), 4.18$ (1 $\mathrm{H}, \mathrm{d}, \mathrm{J}=7.4 \mathrm{~Hz}, \mathrm{H}-3 \mathrm{a}), 3.16(1 \mathrm{H}, \mathrm{d}, \mathrm{J}=5.0 \mathrm{~Hz}, \mathrm{OH}) ;{ }^{13} \mathrm{C}$ $\mathrm{NMR}\left(\mathrm{CDCl}_{3}, 75 \mathrm{MHz}\right) \delta 175.5$ (s), 139.8 (s), 138.3 (s), 130.7 (d), 127.4 (d), 126.3 (d), 125.3 (d), 125.1 (d), 123.6 (d), 122.7 (d), 119.5 (d), 84.9 (d), 72.0 (s), 70.6 (d), 54.2 (d); MS m/z (rel intensity) $336\left(33, \mathrm{M}^{+}\right), 224$ (100), 206 (73), 179 (46), 113 (65); HRMS calcd for $\mathrm{C}_{15} \mathrm{H}_{12} \mathrm{O}_{3} \mathrm{~S}_{3} 335.9949$, found 335.9946

Compound 8 existed as a mixture of two isomers (3:2). The diastereomeric mixture of 8 (38 $\mathrm{mg}, 0.11 \mathrm{mmol}$ ) was treated with PDC (138 mg, $0.37 \mathrm{mmol})$ and molecular sieves $(4 \AA, 2 \mathrm{~g})$ in $\mathrm{CH}_{2} \mathrm{Cl}_{2}(10 \mathrm{~mL})$ at $25^{\circ} \mathrm{C}$ for $1 \mathrm{~h}$. The mixture was filtered through a pad of silica gel and rinsed with EtOAc/hexane (3: 7). The organic phase was concentrated under reduced pressure and chromatographed on a silica gel column with elution of EtOAc/hexane (1:9) to give the product 10 (22 mg, 59\%). 10: solid; $\mathrm{mp} 109-111^{\circ} \mathrm{C}$; TLC (EtOAc/hexane, 1:9) $\mathrm{R}_{\mathrm{f}}=0.17$; IR (neat) 1773, 1664, 1247, $1165 \mathrm{~cm}^{-1} ;{ }^{1} \mathrm{H} \mathrm{NMR}\left(\mathrm{CDCl}_{3}, 200\right.$ $\mathrm{MHz}) \delta 8.44(1 \mathrm{H}, \mathrm{dd}, \mathrm{J}=2.7,1.2 \mathrm{~Hz}), 7.65(1 \mathrm{H}, \mathrm{dd}, \mathrm{J}=5.1$, $1.2 \mathrm{~Hz}), 7.42-7.40(2 \mathrm{H}, \mathrm{m}), 7.32(1 \mathrm{H}, \mathrm{dd}, \mathrm{J}=5.1,2.7 \mathrm{~Hz})$, $7.16(1 \mathrm{H}, \mathrm{dd}, \mathrm{J}=4.2,2.1 \mathrm{~Hz}), 6.49(1 \mathrm{H}, \mathrm{d}, \mathrm{J}=5.5 \mathrm{~Hz}), 5.96$ $(1 \mathrm{H}, \mathrm{d}, \mathrm{J}=5.5 \mathrm{~Hz}), 5.38(1 \mathrm{H}, \mathrm{d}, \mathrm{J}=7.9 \mathrm{~Hz}), 4.96(1 \mathrm{H}, \mathrm{d}, \mathrm{J}$ $=7.9 \mathrm{~Hz}) ;{ }^{13} \mathrm{C} \mathrm{NMR}\left(\mathrm{CDCl}_{3}, 75 \mathrm{MHz}\right) \delta 184.4(\mathrm{~s}), 170.7(\mathrm{~s})$, 138.0 (s), 137.4 (s), 135.3 (d), 130.8 (d), 128.5 (d), 127.6 (d), 126.0 (d), 125.0 (d), 123.5 (d), 119.0 (d), 83.9 (s), 76.9 (d), 56.8 (d); MS m/z (rel intensity) $334\left(31, \mathrm{M}^{+}\right), 257$ (7), 223 (10), 206 (13), 111 (100); HRMS calcd for $\mathrm{C}_{15} \mathrm{H}_{10} \mathrm{O}_{3} \mathrm{~S}_{3} 333.9792$, found 333.9798.

General Procedure for Sequential Coupling-Alkylation. The THF solution $(40 \mathrm{~mL})$ of $\mathrm{Sml}_{2}(3.6 \mathrm{mmol})$ and HMPA (2.8 mL, $16 \mathrm{mmol}$ ) was prepared by the described general procedure and cooled to $0^{\circ} \mathrm{C}$ in an ice bath. A THF solution ( $2 \mathrm{~mL}$ ) of 3-thiophenecarbaldehyde (224 mg, $2 \mathrm{mmol}$ ) (for self-coupling reactions) or a mixture of 3-thiophenecarbaldehyde (112 mg, $1.0 \mathrm{mmol}$ ) and an appropriate aldehyde (1.2 mmol) in THF ( $2 \mathrm{~mL}$ ) (for cross-coupling reactions) was added dropwise over a period of $2 \mathrm{~min}$. The mixture was stirred for $10 \mathrm{~min}$, and an alkylating agent $(1-2.5 \mathrm{mmol})$ was added. The mixture was stirred at room temperature for a period of $21-27 \mathrm{~h}$ and quenched by addition of saturated $\mathrm{NH}_{4} \mathrm{Cl}_{(\mathrm{aq})}(0.1$ $\mathrm{mL}$ ). The mixture was filtered through a pad of silica gel and rinsed with EtOAc/hexane (1:1). The organic phase was concentrated under reduced pressure and chromatographed on a silica gel column with elution of EtOAc/hexane to give the $\gamma$-lactols 11a-d.

3-(2-Allylsulfanyl)ethenyl-2-hydroxy-5-(3-thienyl)-2,5dihydrofuran (11a) and 3-(2-Allylsulfanyl)ethenyl-5-(3thienyl)-5H-furan-2-one (12a). According to the general procedure, coupling of 3-thiophenecarbaldehyde (224 mg, 2 $\mathrm{mmol}$ ) followed by alkylation with allyl bromide $(0.173 \mathrm{mg}$, 
$2.0 \mathrm{mmol}$ ) gave the $\gamma$-lactol $\mathbf{1 1 a}$ (145 mg, 55\%) as a mixture of two isomers (62:38). Oxidation of $\mathbf{1 1 a}$ (45 mg, $0.17 \mathrm{mmol}$ ) with PDC ( $188 \mathrm{mg}, 0.5 \mathrm{mmol}$ ) at $25^{\circ} \mathrm{C}$ for $3 \mathrm{~h}$ by a procedure similar to that for $\mathbf{1 0}$ gave 12a (35 mg, 77\%). 11a: oil; TLC (EtOAC/ hexane (3:7)) $\mathrm{R}_{\mathrm{f}}=0.31$; IR (neat) 3402, 1570, $1037 \mathrm{~cm}^{-1} ;{ }^{1} \mathrm{H}$ NMR $\left(\mathrm{CDCl}_{3}, 200 \mathrm{MHz}\right) \delta 7.28-7.21(2 \mathrm{H}, \mathrm{m}), 7.09(0.62 \mathrm{H}$, $\mathrm{dd}, \mathrm{J}=4.2,2.0 \mathrm{~Hz}), 7.00(0.38 \mathrm{H}, \mathrm{dd}, \mathrm{J}=4.8,1.1 \mathrm{~Hz}), 6.38(1$ $\mathrm{H}, \mathrm{d}, \mathrm{J}=10.7 \mathrm{~Hz}), 6.26(1 \mathrm{H}, \mathrm{s}), 6.08(0.38 \mathrm{H}, \mathrm{s}), 6.20-6.00(1$ $\mathrm{H}, \mathrm{m}), 5.98(1 \mathrm{H}, \mathrm{d}, \mathrm{J}=10.7 \mathrm{~Hz}), 5.84(0.62 \mathrm{H}, \mathrm{s}), 5.89-5.72$ $(1 \mathrm{H}, \mathrm{m}), 5.24-5.13(2 \mathrm{H}, \mathrm{m}), 3.38(2 \mathrm{H}, \mathrm{d}, \mathrm{J}=7.0 \mathrm{~Hz}), 3.11(1$ $\mathrm{H}, \mathrm{d}, \mathrm{J}=7.8 \mathrm{~Hz}, \mathrm{OH}) ;{ }^{13} \mathrm{C} \mathrm{NMR}\left(\mathrm{CDCl}_{3}, 50 \mathrm{MHz}\right) \delta 142.5(\mathrm{~s})$, 141.5 (s), 136.8 (s), 136.5 (s), 133.5 (d, 2 C), 131.5 (d), 131.4 (d), 130.1 (d), 130.0 (d), 126.4 (d, 2 C), 126.2 (d), 126.1 (d), 122.2 (d, 2 C), 118.2 (t, 2 C), 115.5 (d, 2 C), 103.9 (d), 103.7 (d), 82.8 (d), 82.5 (d), 37.4 (t, 2 C); MS m/z (rel intensity) $266\left(10, \mathrm{M}^{+}\right)$, 141 (100); HRMS calcd for $\mathrm{C}_{13} \mathrm{H}_{14} \mathrm{O}_{2} \mathrm{~S}_{2} 266.0435$, found 266.0421. 12a: oil; TLC (EtOAc/hexane, 1:9) $R_{f}=0.12$; IR (neat) 3498 (overtone), 1747, $1624 \mathrm{~cm}^{-1} ;{ }^{1} \mathrm{H}$ NMR $\left(\mathrm{CDCl}_{3}, 200 \mathrm{MHz}\right) \delta 7.47$ $(1 \mathrm{H}, \mathrm{d}, \mathrm{J}=2.0 \mathrm{~Hz}), 7.35-7.32(2 \mathrm{H}, \mathrm{m}), 7.01(1 \mathrm{H}, \mathrm{dd}, \mathrm{J}=$ 4.0, $2.2 \mathrm{~Hz}), 6.64(1 \mathrm{H}, \mathrm{d}, \mathrm{J}=10.7 \mathrm{~Hz}), 6.29(1 \mathrm{H}, \mathrm{d}, \mathrm{J}=10.7$ $\mathrm{Hz}), 6.07(1 \mathrm{H}, \mathrm{d}, \mathrm{J}=2.0 \mathrm{~Hz}), 5.90-5.73(1 \mathrm{H}, \mathrm{m}), 5.28-5.17$ $(2 \mathrm{H}, \mathrm{m}), 3.45(2 \mathrm{H}, \mathrm{dd}, \mathrm{J}=7.1,1.0 \mathrm{~Hz}) ;{ }^{13} \mathrm{C} \mathrm{NMR}\left(\mathrm{CDCl}_{3}, 50\right.$ $\mathrm{MHz} \delta 172.6$ (s), 145.9 (d), 136.0 (s), 134.8 (d), 133.0 (d), 128.0 (s), 127.0 (d), 125.7 (d), 123.9 (d), 118.8 (t), 112.8 (d), 78.6 (d), 37.6 (t); MS m/z (rel intensity) $264\left(35, \mathrm{M}^{+}\right.$), 111 (100); HRMS calcd for $\mathrm{C}_{13} \mathrm{H}_{12} \mathrm{O}_{2} \mathrm{~S}_{2} 264.0279$, found 264.0283 .

3-(2-Benzylsulfanyl)ethenyl-5-(3-thienyl)furan (13a). Compound $\mathbf{1 1 b}(85 \mathrm{mg}, 0.27 \mathrm{mmol}$ ) was treated with $0.01 \mathrm{~N}$ $\mathrm{HCl}$ in $\mathrm{CHCl}_{3}(5 \mathrm{~mL})$ for $5 \mathrm{~min}$. The sol ution was concentrated under reduced pressure to give (Z)-13a (80 mg, 100\%), which isomerized in part ( $\mathrm{Z} / \mathrm{E}=2: 3$ ) on filtration through a pad of silica gel. (Z)-13a: oil; TLC (EtOAc/hexane, 1:19) $\mathrm{R}_{\mathrm{f}}=0.37$; IR (neat) 3104, 1493, $779 \mathrm{~cm}^{-1}$; ${ }^{1} \mathrm{H} \mathrm{NMR}\left(\mathrm{CDCl}_{3}, 300 \mathrm{MHz}\right) \delta$ $7.56(1 \mathrm{H}, \mathrm{s}), 7.45-7.44(1 \mathrm{H}, \mathrm{m}), 7.37-7.24(7 \mathrm{H}, \mathrm{m}), 6.69(1$ $\mathrm{H}, \mathrm{s}), 6.22(1 \mathrm{H}, \mathrm{d}, \mathrm{J}=10.4 \mathrm{~Hz}), 6.13(1 \mathrm{H}, \mathrm{d}, \mathrm{J}=10.4 \mathrm{~Hz})$, $4.00(2 \mathrm{H}, \mathrm{s}) ;{ }^{13} \mathrm{C} \mathrm{NMR}\left(\mathrm{CDCl}_{3}, 75 \mathrm{MHz}\right) \delta 150.8(\mathrm{~s}), 140.4(\mathrm{~d})$, 137.4.(s), 132.3 (s), 128.9 (d, 2 C), 128.7 (d, 2 C), 127.4 (d), 126.1 (d), 124.8 (d), 124.7 (d), 124.2 (s), 119.2 (d), 116.4 (d), 105.5 (d), 38.8 (t); MS m/z (rel intensity) $298\left(87, \mathrm{M}^{+}\right.$), 91 (100); HRMS calcd for $\mathrm{C}_{17} \mathrm{H}_{14} \mathrm{OS}_{2} 298.0486$, found 298.0481. (E)13a: ${ }^{1} \mathrm{H}$ NMR $\left(\mathrm{CDCl}_{3}, 300 \mathrm{MHz}\right) \delta 7.47(1 \mathrm{H}, \mathrm{s}), 7.45-7.27(8$ $\mathrm{H}, \mathrm{m}), 6.51(1 \mathrm{H}, \mathrm{s}), 6.47(1 \mathrm{H}, \mathrm{d}, \mathrm{J}=15.4 \mathrm{~Hz}), 6.39(1 \mathrm{H}, \mathrm{d}, \mathrm{J}$ $=15.4 \mathrm{~Hz}), 3.97(2 \mathrm{H}, \mathrm{s}) ;{ }^{13} \mathrm{C} \mathrm{NMR}\left(\mathrm{CDCl}_{3}, 75 \mathrm{MHz}\right) \delta 151.6$ (s), 138.1 (d), 137.2 (s), $132.2(\mathrm{~s}), 128.7$ (d, 2 C), $128.6(\mathrm{~d}, 2 \mathrm{C})$, 127.2 (d), 126.2 (d), 125.4 (s), 124.5 (d), 123.3 (d), 119.4 (d), 118.7 (d), 102.0 (d), $37.4(\mathrm{t})$.

2-(Thiophene-3-carbonyl)thiophene-3-carbaldehyde (14a). By a procedure similar to that for $\mathbf{1 0}$, oxidation of $\mathbf{7 a}$ (120 mg, $0.53 \mathrm{mmol}$ ) with PDC (414 mg, $1.1 \mathrm{mmol}$ ) and molecular sieves $(4 \AA, 2 \mathrm{~g})$ in $\mathrm{CH}_{2} \mathrm{Cl}_{2}(15 \mathrm{~mL})$ at $25^{\circ} \mathrm{C}$ for 2.5 h gave $14 a$ (101 mg, 86\%). 14a: solid; $\mathrm{mp} 111.5-112.0{ }^{\circ} \mathrm{C}$; TLC (EtOAc/hexane, 3:17) $\mathrm{R}_{\mathrm{f}}=0.24$; IR (KBr) 1675, $1614 \mathrm{~cm}^{-1}$; ${ }^{1} \mathrm{H} \mathrm{NMR}\left(\mathrm{CDCl}_{3}, 200 \mathrm{MHz}\right) \delta 10.21(1 \mathrm{H}, \mathrm{s}, \mathrm{CHO}), 8.13-8.11$ $(1 \mathrm{H}, \mathrm{m}), 7.66-7.61(2 \mathrm{H}, \mathrm{m}), 7.50(1 \mathrm{H}, \mathrm{d}, \mathrm{J}=4.8 \mathrm{~Hz}), 7.42-$ $7.38(1 \mathrm{H}, \mathrm{m}) ;{ }^{13} \mathrm{C} \mathrm{NMR}\left(\mathrm{CDCl}_{3}, 50 \mathrm{MHz}\right) \delta 186.0(\mathrm{~d}, \mathrm{CHO})$, 180.6 (s), 146.8 (s), 144.6 (s), 142.0 (s), 134.7 (d), 129.8 (d), 128.1 (d), 127.9 (d), 127.0 (d); MS m/z (rel intensity) 222 (100, $\mathrm{M}^{+}$); HRMS calcd for $\mathrm{C}_{10} \mathrm{H}_{6} \mathrm{O}_{2} \mathrm{~S}_{2} 221.9809$, found 221.9810 .

4-(3-Thienyl)thieno[2,3-d]pyridazine (15a). A mixture of $14 a$ (12 $\mathrm{mg}, 0.054 \mathrm{mmol}$ ) and hydrazine monohydrate (0.1 $\mathrm{mL}, 2 \mathrm{mmol})$ in EtOH $(10 \mathrm{~mL})$ was stirred at $25^{\circ} \mathrm{C}$ for $10 \mathrm{~min}$ and then heated at reflux for $20 \mathrm{~min}$. The mixture was concentrated and chromatographed on a silica gel column by elution with EtOAc/hexane (1:1) to give 15a (11 mg, 94\%). 15a: solid; $\mathrm{mp} 78-79^{\circ} \mathrm{C}$; TLC (EtOAc/hexane, $\left.1: 1\right) \mathrm{R}_{\mathrm{f}}=0.13$; IR (KBr) 1527, 1461, 1312, 863, 782, $660 \mathrm{~cm}^{-1}$; ${ }^{1} \mathrm{H}$ NMR $\left(\mathrm{CDCl}_{3}, 200 \mathrm{MHz}\right) \delta 9.44(1 \mathrm{H}, \mathrm{s}), 8.17(1 \mathrm{H}, \mathrm{dd}, \mathrm{J}=2.8,1.3$ $\mathrm{Hz}), 7.99(1 \mathrm{H}, \mathrm{dd}, \mathrm{J}=5.0,1.3 \mathrm{~Hz}), 7.84(1 \mathrm{H}, \mathrm{d}, \mathrm{J}=5.4 \mathrm{~Hz})$, $7.52(1 \mathrm{H}, \mathrm{d}, \mathrm{J}=5.4 \mathrm{~Hz}), 7.49(1 \mathrm{H}, \mathrm{dd}, \mathrm{J}=5.0,2.8 \mathrm{~Hz}) ;{ }^{13} \mathrm{C}$ $\mathrm{NMR}\left(\mathrm{CDCl}_{3}, 50 \mathrm{MHz}\right) \delta 151.1$ (s), 144.9 (d), 138.2 (s), 137.1 (s), 136.6 (s), 132.9 (d), 127.3 (d), 126.5 (d), 126.4 (d), 122.8 (d); $\mathrm{MS} \mathrm{m} / \mathrm{z}$ (rel intensity) $218\left(100, \mathrm{M}^{+}\right)$; HRMS calcd for $\mathrm{C}_{10} \mathrm{H}_{6} \mathrm{~N}_{2} \mathrm{~S}_{2} 217.9973$, found 217.9975 .

3-(3-Thienyl)thieno[2,3-c]thiophene (16a). Compound 7a (80 mg, $0.357 \mathrm{mmol}$ ) was treated with Lawesson's reagent
(289 $\mathrm{mg}, 0.714 \mathrm{mmol}$ ) in refluxing 1,4-dioxane $(10 \mathrm{~mL})$ for 3 h. The mixture was cooled, concentrated, and chromatographed on a silica gel column by elution with EtOAc/hexane (1:19) to give 16a (67 mg, 85\%). 16a: oil; TLC (EtOAc/hexane, 1:9) $\mathrm{R}_{\mathrm{f}}=0.64$; IR (neat) $1367,1092,746 \mathrm{~cm}^{-1}$; ${ }^{1} \mathrm{H} \mathrm{NMR}\left(\mathrm{CDCl}_{3}\right.$, $200 \mathrm{MHz}) \delta 7.44-7.39(3 \mathrm{H}, \mathrm{m}), 7.35(1 \mathrm{H}, \mathrm{d}, \mathrm{J}=5.5 \mathrm{~Hz}), 7.22$ $(1 \mathrm{H}, \mathrm{s}), 6.90(1 \mathrm{H}, \mathrm{d}, \mathrm{J}=5.5 \mathrm{~Hz}) ;{ }^{13} \mathrm{C} \mathrm{NMR}\left(\mathrm{CDCl}_{3}, 75 \mathrm{MHz}\right)$ $\delta 147.9(\mathrm{~s}), 134.6(\mathrm{~s}), 134.4(\mathrm{~s}), 132.1(\mathrm{~d}), 126.5(\mathrm{~d}), 125.8(\mathrm{~d})$, 124.2 (s), 119.5 (d), 117.3 (d), 109.9 (d); MS m/z (rel intensity) $222\left(100, \mathrm{M}^{+}\right)$; HRMS calcd for $\mathrm{C}_{10} \mathrm{H}_{6} \mathrm{~S}_{3}$ 221.9632, found 221.9635.

4-Hydroxy-5,6-bis(methoxycarbonyl)-7-(3-thienyl)benzo[b]thiophene (19a). A mixture of $7 a(79 \mathrm{mg}, 0.352 \mathrm{mmol}$ ) and dimethyl acetylenedicarboxylate (DMAD, $50 \mathrm{mg}, 0.352$ $\mathrm{mmol}$ ) was treated with $20 \mathrm{~mol} \%$ PPTS (18 mg, $0.071 \mathrm{mmol}$ ) in refluxing benzene ( $30 \mathrm{~mL}$ ) for $2 \mathrm{~h}$. A Dean-Stark apparatus was equipped for the removal of water. The mixture was cooled, filtered through a pad of silica gel, and rinsed with EtOAc/hexane (1:1). The organic phase was concentrated and chromatographed on a silica gel column by elution with EtOAC hexane (1:4) to give 19a (112 mg, 91\%). 19a: solid; $\mathrm{mp} \mathrm{108-}$ $110^{\circ} \mathrm{C}$ (lit. ${ }^{16 a} 107-109^{\circ} \mathrm{C}$ ); TLC (EtOAc/hexane, 1:4) $\mathrm{R}_{\mathrm{f}}=0.26$; IR (neat) 1733, $1668 \mathrm{~cm}^{-1}$; ${ }^{1} \mathrm{H}$ NMR $\left(\mathrm{CDCl}_{3}, 300 \mathrm{MHz}\right) \delta 11.88$ $(1 \mathrm{H}, \mathrm{s}), 7.63(1 \mathrm{H}, \mathrm{d}, \mathrm{J}=5.4 \mathrm{~Hz}), 7.40-7.37(3 \mathrm{H}, \mathrm{m}), 7.20(1$ $\mathrm{H}, \mathrm{dd}, \mathrm{J}=5.0,1.2 \mathrm{~Hz}), 3.91(3 \mathrm{H}, \mathrm{s}), 3.64(3 \mathrm{H}, \mathrm{s}) ;{ }^{13} \mathrm{C} \mathrm{NMR}$ $\left(\mathrm{CDCl}_{3}, 75 \mathrm{MHz}\right) \delta 170.1$ (s), 168.8 (s), 157.7 (s), 147.9 (s), 136.8 (s), 130.1 (s), 129.3 (s), 128.3 (d), 127.5 (d), 125.6 (d), 124.8 (d), 122.0 (d), 121.3 (s), 103.8 (s), 52.9 (q), 52.1 (q); MS m/z (rel intensity) $348\left(90, \mathrm{M}^{+}\right), 316(100)$.

N-Phenyl-7-(3-thienyl)benzo[b]thiophene-5,6-dicarboximide (20a). By a procedure similar to that for $19 \mathbf{a}$, a mixture of $7 \mathbf{a}(79 \mathrm{mg}, 0.352 \mathrm{mmol})$ and $\mathrm{N}$-phenylmaleimide (61 mg, $0.352 \mathrm{mmol}$ ) was treated with $20 \mathrm{~mol} \%$ PPTS (18 mg, $0.071 \mathrm{mmol})$ in refluxing benzene $(30 \mathrm{~mL})$ for $2 \mathrm{~h}$ to give $20 \mathrm{a}$ (113 mg, 89\%). 20a: solid; $\mathrm{mp} 250-252{ }^{\circ} \mathrm{C}$; TLC (EtOAcl hexane, 3:7) $\mathrm{R}_{\mathrm{f}}=0.31$; IR (neat) $1762,1712 \mathrm{~cm}^{-1} ;{ }^{1} \mathrm{H} \mathrm{NMR}$ $\left(\mathrm{CDCl}_{3}, 200 \mathrm{MHz}\right) \delta 8.33(1 \mathrm{H}, \mathrm{s}), 7.79-7.75(2 \mathrm{H}, \mathrm{m}), 7.59$ (1 $\mathrm{H}, \mathrm{d}, \mathrm{J}=5.5 \mathrm{~Hz}), 7.50-7.32(7 \mathrm{H}, \mathrm{m}) ;{ }^{13} \mathrm{C} \mathrm{NMR}\left(\mathrm{CDCl}_{3}, 50\right.$ $\mathrm{MHz}) \delta 167.0$ (s), 166.7 (s), 146.9 (s), 143.4 (s), 134.4 (s), 132.6 (d), $131.8(\mathrm{~s}), 131.7(\mathrm{~s}), 129.1(\mathrm{~s}), 129.0(\mathrm{~d}, 3 \mathrm{C}), 128.0(\mathrm{~d}), 126.7$ (d, 2 C), 126.5 (d), 125.6 (d), 125.4 (d), 121.8 (s), 118.5 (d); MS $\mathrm{m} / \mathrm{z}$ (rel intensity) $361\left(100, \mathrm{M}^{+}\right)$; HRMS calcd for $\mathrm{C}_{20} \mathrm{H}_{11} \mathrm{NO}_{2} \mathrm{~S}_{2}$ 361.0231, found 361.0242. Anal. Calcd for $\mathrm{C}_{20} \mathrm{H}_{11} \mathrm{NO}_{2} \mathrm{~S}_{2}$ : C, 66.48; H, 3.07; N, 3.88. Found: C, 65.85; H, 2.99; N, 3.80.

7-(4-Methylphenyl)benzo[b]thiophene-5,6-dicarboxylic anhydride (21). By a procedure similar to that for $19 a$, a mixture of 7c $(90 \mathrm{mg}, 0.388 \mathrm{mmol})$ and maleic anhydride (38 mg, $0.388 \mathrm{mmol}$ ) was treated with $20 \mathrm{~mol} \%$ PPTS ( $20 \mathrm{mg}$, $0.078 \mathrm{mmol})$ in refluxing benzene $(30 \mathrm{~mL})$ for $2 \mathrm{~h}$ to give $\mathbf{2 1}$ (76 mg, 67\%). 21: solid; mp 170-172 ${ }^{\circ} \mathrm{C}$; TLC (EtOAc/hexane, 3:7) $\mathrm{R}_{\mathrm{f}}=0.40$; IR (neat) 1838, $1772 \mathrm{~cm}^{-1}$; ${ }^{1} \mathrm{H} \mathrm{NMR}\left(\mathrm{CDCl}_{3}\right.$, $300 \mathrm{MHz}) \delta 8.36(1 \mathrm{H}, \mathrm{s}), 7.87(1 \mathrm{H}, \mathrm{d}, \mathrm{J}=5.3 \mathrm{~Hz}), 7.63(1 \mathrm{H}$, $\mathrm{d}, \mathrm{J}=5.3 \mathrm{~Hz}), 7.50(2 \mathrm{H}, \mathrm{d}, \mathrm{J}=8.0 \mathrm{~Hz}), 7.35(2 \mathrm{H}, \mathrm{d}, \mathrm{J}=8.0$ $\mathrm{Hz}), 2.46(3 \mathrm{H}, \mathrm{s}) ;{ }^{13} \mathrm{C} \mathrm{NMR}\left(\mathrm{CDCl}_{3}, 50 \mathrm{MHz}\right) \delta 163.2(\mathrm{~s}), 162.1$ (s), $148.2(\mathrm{~s}), 144.5(\mathrm{~s}), 140.1$ (s), $138.8(\mathrm{~s}), 134.6(\mathrm{~d}), 130.6$ (s), 129.4 (d, 2 C), 128.9 (d, 2 C), 127.9 (s), 125.4 (d), 120.7 (s), 120.0 (d), 21.5 (q); MS m/z (rel intensity) $294\left(100, M^{+}\right) ;$HRMS calcd for $\mathrm{C}_{17} \mathrm{H}_{10} \mathrm{O}_{3} \mathrm{~S} 294.0351$, found 294.0348.

Acknowledgment. We thank the National Science Council for financial support (Grant NSC87-2113-M002042).

Supporting Information Available: Additional experimental procedures, ORTEP drawing and crystal data of compound $\mathbf{4 a}$, and spectral data of new compounds (52 pages). This material is contained in libraries on microfiche, immediately follows this article in the microfilm version of the journal, and can be ordered from the ACS; see any current masthead page for ordering information.

J O980851D 